\title{
Beliefs about English Language Learning Held by EFL Pre-Service and In-Service Teachers in Lao People's Democratic Republic
}

\author{
Athithouthay Chatouphonexay ${ }^{1} \&$ Channarong Intaraprasert ${ }^{1}$ \\ ${ }^{1}$ School of Foreign Languages, Suranaree University of Technology, Thailand \\ Correspondence: Athithouthay Chatouphonexay, School of Foreign Languages, Suranaree University of \\ Technology, Nakhon Ratchasima 30000, Thailand. E-mail: athithouthay@gmail.com
}

Received: November 25, 2013 Accepted: December 30, 2013 Online Published: February 12, 2014

doi:10.5539/elt.v7n3p1 URL: http://dx.doi.org/10.5539/elt.v7n3p1

\begin{abstract}
The present investigation aims to explore the existence of similarities and differences of beliefs about English Language learning held by EFL pre-service and in-service teachers in Lao P.D.R. A total of 962 pre-service teachers and 129 in-service teachers from 3 universities and 8 Teachers' Training Colleges were involved in this study. Two questionnaires were used to collect the data. Chi-square $\left(x^{2}\right)$ tests were used to analyze the quantitative data from both pre-service teachers' and in-service teachers' questionnaires. The results of the chi-square $\left(x^{2}\right)$ tests revealed that 13 out of 39 items of beliefs varied significantly between pre-service and in-service teachers.
\end{abstract}

Keywords: English language learning, learners' beliefs, teachers' beliefs, pre-service and in-service teachers, EFL

\section{Introduction}

Pre-service and In-service teachers come to any teacher education program with prior experiences, knowledge and beliefs about learning and teaching English. Pre-service and In-service teachers' prior knowledge and beliefs have an effective role in developing them as prospective teachers and teachers.

Since the 1980s, language learners' beliefs, with the influence of research in cognitive psychology, have received remarkable attention by researchers (Horwitz, 1987a; Wenden, 1986a, 1986b, 1999). Horwitz (1987b) developed an instrument, Beliefs about Language Learning Inventory (BALLI), to assess learners' beliefs about language learning in five major areas: (1) The difficulty of language learning; (2) Foreign language aptitude; (3) The nature of language learning; (4) Learning and communication strategies; and (5) motivation and expectations. Since then, BALLI questionnaires have been widely used or modified for use by some researchers in investigating learners' beliefs in second or foreign language settings.

Learners' beliefs about language learning not only have the potential to influence learners' experience and actions as language learners but also have direct or indirect effects on learners' behavior (Wen \& Johnson, 1997), and they may directly influence or even determine a learner's attitudes toward language and language learning or his/her motivation (Riley, 1996). Moreover, the preconceived beliefs about language learning would be likely to affect the way the learners use their learning strategies to learn a second or foreign language (Horwitz, 1987a, 1988; Wenden, 1986a, 1987a). Kagan (1992, p. 85) also affirms that the study of beliefs is critical to educational practice since beliefs may be "the clearest measure of a teacher's professional growth".

A number of studies have been conducted in the past two decades to examine beliefs about language learning of various groups of second /foreign language learners including native English speakers studying foreign languages (Horwitz, 1988; Kern, 1995; Mori, 1999), ESL learners (Cotterall, 1995; Horwitz, 1987; Wenden, 1986, 1987), EFL learners (Peacock, 1999; Sakui \& Gaies, 1999; Truitt, 1995; Wen \& Johnson, 1997; Yang, 1999), and non-native English speakers such as Thai and Vietnamese university science-oriented students (Intaraprasert, 2004), Chinese university students and teachers in the People's Republic of China (Wang, 2008), and Turkish pre-service teachers' language learning beliefs and effects of these beliefs on their practice teaching (Incecay, 2011), and relationships among beliefs in learning English of Thai graduate students in a public university (Suwanarak, 2013). Furthermore, in some studies, the relationships between learners' beliefs about language learning and factors that can affect language learning success such as motivation, readiness and 
self-competency, language learning strategies, and anxiety were investigated (Yang \& Peacock, 1999). Besides, some beliefs about language learning have been found to correlate with English proficiency. As cited in Vibulphol (2004), these findings suggest that second language teachers, with an understanding of learners' beliefs about language learning, can help enhance learners' success in language learning two ways: by promoting their students' beliefs that are facilitative to language learning e.g. "I believe that I will ultimately learn to speak English well" "I have English Language aptitude" and by refining those that are debilitative. e.g. "English is a difficult language" or "I learn English only to pass the exam".

The studies of teacher's beliefs about language learning include not only in-service teachers but also pre-service teachers. Having taken into consideration the possible effects of teacher's beliefs on their instructional practices which consequently affect learners' learning experiences, some researchers have examined the development of teacher's beliefs during teacher education programs. As found in Horwitz (1985), pre-service second language teachers enter teacher education programs with pre-existing ideas about language and language learning, just like second language learners.

Even though a substantial number of studies have been conducted to examine pre-service teachers' beliefs about teaching and learning during their teacher education programs, no attempt has been made in investigating or examining the existing differences between pre-service and in-service teachers' beliefs in the Lao tertiary context. As a result, the general objective of this investigation aims to explore the existence of differences of beliefs held by EFL pre-service and in-service teachers in Lao P.D.R.

\section{Review of Related Literature}

Recently, there has been an increased focus on learners' and teachers' beliefs in relation to the nature of language learning and teaching in an attempt to account for individual differences in language learning (Cotteral, 1995; Horwitz, 1988; Kern, 1995; Wenden, 1986a). Therefore, beliefs about English language learning have become one of the most widely discussed topics in the field of both general education and teacher education.

\subsection{Pre-Service Teachers' Beliefs about Language Learning}

Based on the findings about the relationships between teachers' beliefs and their instructional practices, researchers have been interested in investigating how pre-service teachers' beliefs are developed. As suggested by the assumptions about the development of beliefs, researchers assume that pre-service teachers enter teacher education programs with preconceived ideas about learning and teaching that are from two main sources namely: (1) their learning experience as language learners, and (2) experiences from teacher education programs.

Lortie's (1975) apprenticeship of observation is a phenomenon that is well known among researchers in the field. He proposed that pre-service teachers started their apprenticeship when they were students, and thus they started developing their beliefs about teaching and learning early from that experience. He found that there is a connection between teachers' current classroom practices and those of their teachers. The findings from Johnson (1994) lend support to this. She found that pre-service teachers' instructional practices were influenced by their experiences from their formal learning. Researchers propose that pre-service teachers' beliefs about learning and teaching may be influenced by the ideas they learned from their teaching methodology classes or by the experiences they gained during their practice teaching program (Johnson, 1994; Horwitz, 1985; Kern, 1995; Richards \& Lockhart, 1994).

However, some researchers argue that beliefs of advanced language learners, like those of pre-service teachers, may not be influenced by the experiences from the teacher education program. Tatto (1998) claimed that "Little empirical evidence exists on the influence of teacher education on teachers' values and beliefs. Consensus exists that teacher education has little effect on altering teachers' beliefs" (p. 66).

Considering the complex and idiosyncratic nature of beliefs, Wenden (1998) proposed that beliefs are relatively stable. Similarly, Dole and Sinatra (1994) supported that it is not easy for beliefs to change, especially the central change or permanent change in beliefs.

\subsection{In-Service Teachers'Beliefs about Language Learning}

Research interests in beliefs about language learning are not limited to those of language learners. Several studies have investigated beliefs about the language learning of both in-service and pre-service teachers. These studies were designed based on the hypothesis that teachers' beliefs may influence learners' beliefs through instructional practices.

Teachers' beliefs represent a complex and inter-related system of personal and professional knowledge. Kagan (1992, p. 85) argues that teachers' beliefs may be "the clearest measure of a teachers' professional growth" that 
understanding them is "instrumental in determining the quality of interaction one finds among teachers in a given school". The study of teachers' beliefs forms part of the process of understanding how teachers conceptualize their work (Richards, Gallo, \& Renandya, 2001).

The difference between knowledge and beliefs is that when information (i.e. knowledge) is not available, teachers will rely on beliefs to guide them. Subsequently, a number of further definitions have been developed to deal with the complex area of types of knowledge and beliefs.

In terms of the definition of teachers' beliefs, Basturkmen, Loewen and Ellis (2004, p. 244) define teachers' beliefs as "statement made about their (teachers') ideas, thoughts, and knowledge that are expressed as evaluations of what 'should be done', 'should be that case', and 'is preferable". Undoubtedly, the beliefs teachers hold influence their perceptions and judgments, which affect their behavior in the classroom, and the materials and activities they choose for the classroom (Pajares, 1992; Hampton, 1994; Borg, 1998). In his recent study, Gan (2004) suggests that teachers' awareness of learners' positive attitudes toward self-directed learning, and a shared view of learners as metacognitively active seekers of knowledge and skill, could have a significant impact on their approach to foreign/second language teaching.

It is important to examine language teachers' beliefs as well as to examine how teachers' beliefs are formed. The majority of past research studies show that the most resilient of 'core' teachers' beliefs are formed from the basis of teachers' own schooling as young students while observing teachers who taught them (Clark \& Peterson, 1986). These beliefs stem from learners' previous learning experience what Lortie (1975) has called 'apprenticeship of observation'.

Another important aspect of teachers' beliefs is the conception of change in the teachers' teaching practice. Hampton (1994, p. 129) suggest that "some of the teachers' beliefs are changeable, but others are impermeable and difficult or impossible to change." Regarding the reasons which result in changes of teachers' beliefs, Richards, Gallo and Renandya (2001, p. 55) conclude that "changes in teachers' practices are the result of changes in teachers' beliefs".

\section{Research Problem}

The research question has been formulated according to the objective of the study. In order to establish some empirical data in the Lao tertiary context, the present investigation has been designed to answer the following specific question: Do beliefs about English language learning held by EFL pre-service teachers and in-service teachers vary significantly? If they do, what are the main variation patterns?

\section{Significance of the Study}

Firstly, according to Cheng (2000), language learning is an extremely complex process, which is further complicated by the learners' individual differences and their different social, political and cultural backgrounds. It is also important to look at the learners' beliefs within their certain cultural context. In the fields of applied linguistics and second language acquisition, researchers have been long on assumptions and short on rigorous empirical research when it comes to Asian learners (Young, 1987; Gu, 2002). Asian learners of English have been reported as reticent and passive learners. They are described as over-dependent on their teachers, reluctant to participate in classroom discourse, unwilling to give responses in class, inclined to rote learning and unable to engage in independent learning (Jones, 1999; Bradock et al., 1995; Cortazzi \& Jin, 1996; Tsui, 1996). These allegations are often associated with the Confucian cultural heritage which values teacher authority (Oxford \& Burry-Stock, 1995; Cortazzi \& Jin, 1996). In a more recent study, Cheng (2000) has concluded that sweeping generalizations about Asian learners are largely based on anecdotal evidence.

Secondly, it is widely accepted that language learning is fully situated within a given cultural context (Ellis, 1994). As a result, different cultural backgrounds are one of the important factors which shape beliefs about foreign language learning (Horwitz, 1987a). While research on learners' beliefs has covered some important areas in the second /foreign language learning in diverse contexts, however, no research has been conducted to explore learners' and teachers' beliefs about English as foreign language learning at the tertiary level in the Lao context so far. Therefore, it is important to explore precisely what beliefs are held by Lao university and college teacher students and their teachers of English in order to fill this gap. To the researcher's expectation, the present research results may shed some light on one aspect of pre-service and in-service teachers' beliefs about English as a foreign language in the Lao context, which is quite different from English as second language learning in other geographical areas.

Finally, the results of this study may be able to shed some light on teachers' instructional practice in the classroom, on learners' learning and also provide guidance on syllabus development and materials revision in the 
future teacher education in Laos. At least a way can be found to narrow or bridge the gap in beliefs between learners and their teachers in general and EFL pre-service and in-service teachers in particular.

\section{Method}

\subsection{Participants}

962 pre-service teachers ( 472 males and 490 females), and 129 in-service teachers (57 university teachers and 72 college teachers) of English from 3 universities (one in the north, one in the central and one in the south of Laos) and 8 Teachers' Training Colleges in Lao P.D.R. participated in this study. Among the pre-service teachers, 480 were English major and 482 were non-English major. All in-service teachers were non-native English teachers.

\subsection{Instrument}

To explore the existence of similarities and differences of beliefs held by EFL pre-service and in-service teachers in Lao P.D.R., the data were obtained through student and teacher questionnaires. The main items of beliefs used in this study were modified based on the Beliefs about Language Learning Inventory (BALLI), Horwitz, 1987b, Cotterall (1995) and Intaraprasert (2004).

Every effort to make the questionnaire valid and reliable has been made. There were versions in English and Lao. The English version was used for discussion purposes for the present investigation and the Lao version was used for the purpose of data collection with EFL pre-service and in-service teachers. These two versions of the belief questionnaire were used as the instrument, as this would help maximize ease of administration and ensure greater accuracy of results. The translation from English into Lao was initially done by the researcher. The student questionnaire was tried out in a pilot study. Similarly, the teacher questionnaire was translated into Lao in order to provide convenience for the teacher participants.

\subsection{Data Collection and Analysis}

Data were obtained by distributing the questionnaires to 962 EFL pre-service teachers and 129 in-service teachers at 3 universities which offer teacher education program and 8 Teachers Training Colleges (during 2012/2013) in order to collect the quantitative data for the present investigation.

Chi-square tests $\left(x^{2}\right)$ were employed to determine the significant variation patterns in learners' and teachers' reported beliefs about learning English as a foreign language at the individual item level. These tests were used to check all the items for significant variations with respect to the variables in the present study. This test compared the actual frequencies with which participants gave different responses on the 5-point rating scale, a method of analysis closer to the raw data than comparisons based on average responses for each item. For the Chi-square tests, responses of 1 and 2 ("Strongly Disagree" and "Disagree") were consolidated into a single "Disagreement" category; responses of 3 "Uncertainty" was one individual category; and responses of 4 and 5 ("Agree" and "Strongly Agree") were combined into a single "Agreement" category. The purpose of consolidating the 5 response levels into three categories of beliefs is to obtain cell sizes with expected values high enough to ensure a valid analysis (Green \& Oxford, 1995, p. 271).

\section{Results}

The results of the chi-square $\left(x^{2}\right)$ tests revealed that 13 out of 39 items of beliefs varied significantly between EFL pre-service and in-service teachers. The significant differences of items ranged from $p<.001$ to $p<.05$. The findings are summarized in Table 1 below:

Table 1. A comparison of beliefs about learning English held by EFL pre-service and in-service teachers

\begin{tabular}{|c|c|c|c|c|}
\hline Students/Teachers & Agreement & Uncertainty & Disagreement & $\begin{array}{l}\text { Observed } x^{2} \\
\mathrm{P}<.05\end{array}$ \\
\hline Students & $89.7 \%$ & $4.4 \%$ & $5.9 \%$ & $\chi^{2}=62.138$ \\
\hline Teachers & $70.5 \%$ & $3.1 \%$ & $26.4 \%$ & $\mathrm{p}<.001$ \\
\hline \multicolumn{5}{|c|}{ Item 5. Students believe that they will ultimately learn to speak English very well. } \\
\hline Students & $58.7 \%$ & $38.5 \%$ & $2.8 \%$ & $\chi^{2}=24.370$ \\
\hline Teachers & $50.4 \%$ & $38.0 \%$ & $11.6 \%$ & $\mathrm{p}<.001$ \\
\hline \multicolumn{5}{|c|}{ Item 13. It is OK to guess if students do not know the meaning of a new word in English. } \\
\hline Students & $47.6 \%$ & $21.8 \%$ & $30.6 \%$ & $\chi^{2}=52.606$ \\
\hline
\end{tabular}




\begin{tabular}{|c|c|c|c|c|}
\hline Teachers & $81.4 \%$ & $5.4 \%$ & $13.2 \%$ & $\mathrm{p}<.001$ \\
\hline \multicolumn{5}{|c|}{ Item 14. Students have English language aptitude. } \\
\hline Students & $33.9 \%$ & $44.8 \%$ & $21.3 \%$ & \multirow{2}{*}{$\begin{array}{l}\chi^{2}=15.156 \\
\mathrm{p}<.001\end{array}$} \\
\hline Teachers & $24.8 \%$ & $62.8 \%$ & $12.4 \%$ & \\
\hline \multicolumn{5}{|c|}{ Item 15. Learning English is mostly a matter of learning a lot of new vocabulary words. } \\
\hline Students & $82.5 \%$ & $11.7 \%$ & $5.7 \%$ & \multirow{2}{*}{$\begin{array}{l}\chi^{2}=12.675 \\
p<.05\end{array}$} \\
\hline Teachers & $71.3 \%$ & $15.5 \%$ & $13.2 \%$ & \\
\hline \multicolumn{5}{|c|}{ Item 20. Learning English is a matter of learning a lot of grammar rules. } \\
\hline Students & $76.9 \%$ & $11.3 \%$ & $11.7 \%$ & \multirow{2}{*}{$\begin{array}{l}\chi^{2}=52.936 \\
p<.001\end{array}$} \\
\hline Teachers & $51.2 \%$ & $14.0 \%$ & $34.9 \%$ & \\
\hline \multicolumn{5}{|c|}{ Item 21. Students would like to learn English so that they can make friends with foreigners. } \\
\hline Students & $64.6 \%$ & $19.1 \%$ & $16.3 \%$ & \multirow{2}{*}{$\begin{array}{l}\chi^{2}=86.303 \\
p<.001\end{array}$} \\
\hline Teachers & $23.3 \%$ & $33.3 \%$ & $43.4 \%$ & \\
\hline \multicolumn{5}{|c|}{ Item 25. It is important to learn English trough translation from English into Lao and Lao into English. } \\
\hline Students & $90.1 \%$ & $7.7 \%$ & $2.2 \%$ & \multirow{2}{*}{$\begin{array}{l}\chi^{2}=53.554 \\
p<.001\end{array}$} \\
\hline Teachers & $69.8 \%$ & $17.8 \%$ & $12.4 \%$ & \\
\hline \multicolumn{5}{|c|}{ Item 26. If students learn to speak English very well, it will help them get a good job. } \\
\hline Students & $85.4 \%$ & $11.6 \%$ & $2.9 \%$ & \multirow{2}{*}{$\begin{array}{l}\chi^{2}=21.080 \\
p<.001\end{array}$} \\
\hline Teachers & $69.8 \%$ & $25.6 \%$ & $4.7 \%$ & \\
\hline \multicolumn{5}{|c|}{ Item 31 . Students would like to have friends from foreign country. } \\
\hline Students & $77.4 \%$ & $16.5 \%$ & $6.0 \%$ & \multirow{2}{*}{$\begin{array}{l}\chi^{2}=93.179 \\
p<.001\end{array}$} \\
\hline Teachers & $38.0 \%$ & $50.4 \%$ & $11.6 \%$ & \\
\hline \multicolumn{5}{|c|}{ Item 32. Laotians can learn and communicate in English. } \\
\hline Students & $77.0 \%$ & $17.0 \%$ & $5.9 \%$ & \multirow{2}{*}{$\begin{array}{l}\chi^{2}=39.668 \\
p<.001\end{array}$} \\
\hline Teachers & $58.1 \%$ & $20.9 \%$ & $20.9 \%$ & \\
\hline \multicolumn{5}{|c|}{ Item 34. It depends on the teacher to make students like or dislike learning English. } \\
\hline Students & $65.6 \%$ & $21.3 \%$ & $13.1 \%$ & \multirow{2}{*}{$\begin{array}{l}\chi^{2}=14.417 \\
p<.001\end{array}$} \\
\hline Teachers & $82.2 \%$ & $10.1 \%$ & $7.8 \%$ & \\
\hline \multicolumn{5}{|c|}{ Item 38. Doing a self-study in English outside class is very helpful. } \\
\hline Students & $86.3 \%$ & $10.6 \%$ & $3.1 \%$ & \multirow{2}{*}{$\begin{array}{l}\chi^{2}=10.048 \\
p<.001\end{array}$} \\
\hline Teachers & $96.1 \%$ & $3.1 \%$ & $0.8 \%$ & \\
\hline
\end{tabular}

\section{Discussion}

Both pre-service and in-service teachers bring their experience to the classroom that influences their perceptions in subtle ways. These beliefs do nevertheless express realities which may influence classroom practices (Richards \& Lockhart, 1994), and directly or indirectly affect their expectations about classroom behaviors (Wright, 1987). According to Eslami-Rasekh and Valizadeh (2004), effective language learning and teaching can only be achieved when teachers are aware of their learners' needs, capabilities, potentials and preferences.

The researcher hypothesized that the more similarities rather than differences of beliefs held between learners and teachers, the more successful and satisfying learning and a teaching environment the learners and teachers would be. In addition, the gradually narrowing gap between learners and teachers will contribute to positive rather than "negative (language learning) outcomes" (Horwitz, 1988, p. 292). The wider mismatch between students' and teachers' beliefs might reveal a wide gap between students and their teachers and might create tension in the classroom (Bernat, 2008), result in negative learning outcomes for learners, reduce learners' confidence in and satisfaction with the class, and lead to a reluctance to participate in communicative activities (Peacock, 1999). Therefore, the wider match between students' and teachers' beliefs in this study revealed a small gap between students and their teachers. This showed that more similarities than differences of beliefs held between pre-service and in-service teachers were found.

Moreover, learners' beliefs have the potential to influence both their experience and actions (Horwitz, 1987a, 1999; Kern, 1995; Mantle-Bromley, 1995; Peacock, 1999). In particular, teachers' beliefs play a major role in defining teaching tasks and organizing the knowledge and information relevant to those tasks (Nespor, 1987, p. 
324). In terms of the difficulty of English language learning, the findings revealed that students and teachers shared the same views on (3) English is a difficult language; (22) It is easier to speak than to understand English; and (33) It is easier to read and write English than to speak and understand it. On the one hand, both students and teachers described English as a difficult language. On the other hand, they regarded the 4 skills of language learning as different learning outcomes. In the Lao context, French is given a status as the 'first foreign language' while English is 'the most important language'. The notion that 'English is the most important language' does not mean it is an easy language. In teacher education program, three years required for a higher diploma of English and four years of a bachelor program of English. In this regard, English is a difficult language means learners have to make great effort in order to become teachers of English. In a mindset of Lao people, it is a kind of success and pride if one's offspring is able to speak a foreign language. As an active learner, the researcher himself can speak two foreign languages such as, French and English. Regarding the language skills, both students and teachers believed that listening or understanding English is more difficult than reading, writing and speaking. In many cases, Lao students and teachers struggled very hard to understand what foreigners had said or talked to each other. Through the informal discussion with some students and teachers at NUOL, the researcher found that most of them felt the listening test of TOEFL and IELTS the most difficult part.

Another point which is worth discussing deals with foreign language aptitude. "Aptitude" is defined as "the ease of learning or understanding", or more simply "intelligence". The capacity of learning is inherent in all humans and the speed or facility to learn depends upon the individual's intelligence. The process of language acquisition uses this intelligence in order to be able to communicate with others in the community (Intaraprasert, 2004, p. $75)$.

In this regard, both students and teachers believed that (1) It is easier for children than adults to learn English; (2) Some people are born with a special ability which helps them learn English; (6) Laotians are good at learning English; (10) People who are good at mathematics or science are not good at learning English; (17) Women are better than men at learning English; and (27) Only a native speaker can teach students to speak English very well. As a result, both EFL pre-service and in-service teachers were confident and optimistic in learning and teaching in the realm of teacher education in Lao.P.D.R. However, the question may be raised whether these phenomena influence people's judgment or it is a result of their subjective experience in life. It can be inferred that intelligence or special foreign language ability alone cannot ultimately determine one's success in English language learning. If both students and teachers believed that they had a certain kind of foreign language aptitude, they might have owed their success in English language learning at least partly to such sort of special ability to a certain degree. However, it may infer that some learners who denied the existence of foreign language aptitude lacked the confidence to learn English well (Peacock, 1999). It may also be that these learners may feel that their failure in English language learning was due to the lack of a foreign language aptitude. Considering the teachers of English as language "experts", the findings seem to reveal that foreign language aptitude has played an important role in these teachers' success in learning English.

In terms of the nature of English language learning, the findings were consistent with what Hinkel (1999) claims is beliefs that (8) It is necessary to know English culture in order to speak English well; (11) It is better to learn English in an English-speaking country; and (24) Learning English is different from learning other school subjects. Hinkel (1999) states that applied linguists and language teachers have become increasingly aware that second or foreign language can rarely be learned or taught without addressing the culture of the community in which it is used. According to Williams and Burden (1997, p. 115), “... learning a foreign language involves far more than simply learning language skills, or a system of rules, or grammar; it involves an alteration in self-image, the adoption of new social and cultural behaviors and ways of being, and therefore has a significant impact on the social nature of the learner". In other words, there is no way to avoid teaching culture when teaching English. Again, in relation to the difference between English and other school subjects, Williams and Burden (1997, p. 115) state that "there is no question that learning a foreign language is different from learning other subjects, mainly because of the social nature of such a venture". Similarly, Gadner (1985, p. 146) agrees that "languages are unlike any other subject taught in a classroom in that they involve the acquisition of skills and behavior patterns which are characteristics of another community'.

With respect to strategy use, both students and teachers believed that (7) It is necessary to speak English with an excellent accent; (9) Students should not say anything in English until they can say it correctly; (18) If you are allowed to make mistakes in the beginning, it will be hard to get rid of such mistakes later on; and (19) Students feel shy or uncomfortable when they speak English in front of other people. One interesting point is that, both students and teachers highly valued a native-like accent in English and placed it as a high priority. However, learners who hold beliefs in speaking English with an excellent accent might care too much about their accent 
rather than other communication strategies. Moreover, they might become more-self conscious to speak English in front of other people and lack confidence to communicate with people in English because of their over-anxiety about their imperfect accent. Similarly, anyone believing that he/she should not say anything until he/she can say it correctly is likely to avoid speaking most of the time (Horwitz, 1987).

Regarding motivation and expectations, both students and teachers agreed that (12) Students can improve their English if they often chat with English native speakers; (30) Nowadays Lao people think it is very important to learn English; (35) Students learn English only to pass the exam; and (36) A teacher should speak Lao as much as he/she can while teaching. In learning English or any other foreign language, motivation seems to play an important role among language learners (Harmer, 1991; Williams \& Burden, 1997; Richards \& Lockhart, 1994). The motivation in language learning can be either integrative or instrumental. According to Williams and Burden (1997), learners differ markedly in their need to achieve or to be successful. In this particular study, it can be assumed that both students and teachers are highly motivated. They expect to use the English language in the real life in order to improve their language proficiency. In the Lao tertiary context, however, both of them normally lack such opportunities at college and university. These findings were also supported by the findings from students' and teachers' interviews. When the students were asked how they apply their English language, many of them responded that "almost no use", except for few students working at restaurants, guest houses, hotels and night clubs after class. In other words, both of them had very limited exposure to the English language.

Another interesting point which should be highlighted here deals with exam. A test is considered as a tool for teachers to check their students' learning to a certain level. In the Lao tertiary context, English language teaching identified in teacher education curriculum of all levels become somewhat exam-oriented. The notion of 'Teach to Test' is something like the alarm clock for learners in order to succeed. As a result, pre-service students in general, and English major students in particular had to take all kinds of exam since they started learning English Obviously, students and teachers shared the same beliefs because of exam predominance in teacher education system. This hot issue is somewhat related to the students' beliefs that a teacher should speak Lao as much as he/she can while teaching. In other words, "English Only" is unwelcome in many circumstances. However, according to Intaraprasert (2004), their belief about this matter might change, so it should be another interesting point to investigate if learner's beliefs can change over time or not in order to understand it better.

With respect to the role of the teacher and feedback, the findings in this study revealed that both students and teachers believed that (28) without a teacher, learning English is impossible for students; and (37) the teacher is the best resource person for me to learn English. In the context of teacher education in Lao P.D.R., Lao people always give high respect to teachers as knowledgeable and trustworthy people who tirelessly devote their lives for the education of future leaders of the nation. In the researcher's opinion, it is not surprising that both students and teachers highly valued the role of teacher as the best resource person in the teaching and learning process. Moreover, learning English at Teachers' Training College or at university is not just only learning a foreign language but it is also a "what to teach and how to teach". This might imply that the role of teacher is twofold which is to teach content knowledge and pedagogical knowledge.

With regard to the role of media utilization in English language learning, both students and teachers believed that (23) Multi-media is very useful in learning English; and (39) It is important to practice English in the language laboratory. The findings revealed that media utilization has become very important for EFL pre-service and in-service teachers in the process of learning English language nowadays. By holding such belief, teachers can create successful learning environment within their institutions.

Another point which is worth discussing here deals with learner's independence. In this study, both students and teachers agreed that (16) It is important to repeat and practise a lot in class; and (29) Extra-curricular activities enable students to learn English well. The findings revealed that students and teachers placed great emphasis on repetition and practice. In the context of Lao teacher education, in order to become effective teacher of English, students have to make great effort in learning not only in class but outside class as well. In other words, to learn English is one thing and to teach English is another thing. There is no short cut and this is not a "wish" but a "need". Through the researcher's teaching experience, he was asked quite often from students on how to be good at learning English. The answer was only one word "PRACTICE and PRACTICE". Nowadays, this issue is very critical since many teacher students did not invest adequate time and energy in self-practice and study.

It is obvious to see that learners' beliefs do influence the actions that learners perform to learn a foreign or second language if the learners are able and prepared to act on their beliefs (Ellis, 2008). As a result, it is also important for teachers to be aware of what beliefs their students hold. 


\section{Implications, Limitations and Recommendations}

In the present study, the more similarities than differences found between students' and teachers' beliefs also implied significant implications for learning and teaching English to a greater extent. In other words, the more similarities rather than differences of beliefs in English language learning, the more successful and satisfying learning and teaching environment will be. Undoubtedly, the gradually narrowing gap between students' and teachers' beliefs will contribute to positive rather than "negative (language learning) outcomes" (Horwitz, 1988, p. 292). Despite the 'static' and 'unchangeable' characteristics of beliefs, it is highly recommended that teachers should help, encourage and promote their students to hold more facilitative or functional beliefs in their English learning. Consequently, the gap between students' and teachers' might become narrower, a successful learning environment might be created, and more positive language outcomes might be achieved ultimately.

In order to help teacher students, in particular those who are English major, teachers should ensure their students that the ability to learn English is not innately fixed but could be improved with commitment, hard work and persistence in learning. Teacher should make their students see that nothing is impossible for them to learn. In addition, teachers should narrow the gap of level of teaching and level of learning as well as to provide opportunities for students to share successful experiences in learning English so that more facilitative or functional beliefs could be promoted and debilitative or dysfunctional beliefs could be avoided.

The present investigation has been valid and valuable in addressing the primary research question, which are to identify the percentages of beliefs about English language learning held by EFL pre-service and in-service teachers, the significant variation patterns in beliefs in terms of different variables, the relationship of beliefs between students and teachers, and particular students' and teachers' beliefs about learning English. However, in carrying out the research, certain limitations have been apparent and areas for possible future research have been discerned. To take the limitations into consideration firstly, the following issues are worthy of attention:

1) Firstly, the data obtained for the present investigation was mainly from two written questionnaires without being verified through other sources such as classroom observation, teacher's lesson plans, or students' diaries. These sources should also have been considered so that more information could have been obtained to triangulate the research findings from various aspects. The combination of more research methods could have allowed the researcher obtain more in-depth information in relation to the formulated research questions.

2) Secondly, open-ended questions about the formation of beliefs in accordance with eight categories should have been included in the two questionnaires in order to explore how these beliefs are formed. By so doing, more information might have been obtained in terms of each category of beliefs held by EFL pre-service and in-service teachers in Lao P.D.R.

3) Thirdly, this particular investigation is limited to the data analysis focusing only on the level of 'Agreement' of beliefs about learning English. The level of 'Uncertainty' and 'Disagreement' should also have been considered so that more information could have been obtained from various dimensions.

4) Finally, since this particular study was carried out among a certain group of participants at eight Teachers' Training Colleges and three universities in Lao P.D.R., the generalization of the findings has to be limited to the similar contexts.

Notwithstanding the limitations, the specific investigation is nonetheless valid. However, the following areas related to beliefs about English language learning might be justified in further research:

1) As shown in the review of related literature, it can be noted that a number of research works examined learners' beliefs in association with English language learning and teaching, use of language learning strategies, and anxiety in the language classroom. The researcher still sees there is a need to replicate research on beliefs about learning English held by students and their teachers of English by examining variables in the other settings of Lao tertiary contexts.

2) As identified in the general education curriculum in Lao P.D.R., English is taught as a foreign language at different levels i.e. from primary school level to lower and upper-secondary level. Beliefs about English language learning held by students are gradually developed through their language experience at different levels of schooling. Therefore more studies are needed in the lower and upper-secondary to explore: (1) percentages of beliefs about English language learning held by the students and their teachers; (2) how the beliefs are formed; and (3) to what degree teachers' beliefs might influence those of their students.

3) Teachers' beliefs in language learning have played an important role in classroom practices. It is important to relate teachers' beliefs to their students' in order that they will be in tune with each other in terms of classroom practices. 
4) It is still essential to explore what relationship exists between beliefs about English language learning held by English major students of the Faculty of Letters and of the Faculty of Education and their teachers at four universities of Lao P.D.R.

\section{Conclusion}

The present investigation gives a comprehensive picture of the EFL pre-service and in-service teachers' beliefs about English language learning in the Lao tertiary context of teacher education. It is a new study in the field of beliefs about learning English as a foreign language in Lao.P.D.R. This study will contribute to the field of research in beliefs about English language learning held by pre-service and in-service teachers. The findings of match between students' and teachers' beliefs have provided certain significant implications for both learning English for students and teaching English for teachers. It can be stated that effective language teaching and learning can only be achieved when teachers are aware of their learners' needs, capabilities, potentials, expectations and preferences. As a result, it is also important for teachers to be aware of what particular belief their students hold.

\section{References}

Basturkmen, H., Loewen, S., \& Ellis, R. (2004). Teachers' stated beliefs about incidental focus on form and their classroom practices. Applied Linguistics, 25, 243-272.

Bernat, E. (2008). Beyond beliefs: psychology-cognitive, socialcultural and emergent ecological approaches to learner perceptions in foreign language acquisition. System, 10, 7-27.

Borg, S. (1998). Teachers' pedagogical systems and grammar teaching: A qualitative study. TESOL Quarterly, 32(1), 9-38.

Bradock, R., Robberts, P., Zheng, C., \& Guzman, T. (1995). Survey on skill development in intercultural teaching of international students. Macquarie University, Asia Pacific Research Institute, Sydney.

Cheng, X. (2000). Asian students' reticence revisited. System, 28, 435-446.

Clark, C. M., \& Peterson, P. L. (1986). Teachers' thought processes. In M. C. Wittrock (Ed.), Handbook of Research on Teaching (3rd ed., pp. 255-296). Macmillan, New York.

Cortazzi, M., \& Jin, L. (1996). English teaching and learning in China. Language Learning, 29(2).

Cotterall, L. S. (1995). Readiness for autonomy: Investigating learner beliefs. System, 23(2), 195-205.

Dole, J. A., \& Sinatra, G. M. (1994). Social psychology research on belief and attitudes: implications for research on learning from text. In A. Garner, \& P. A. Alexander (Eds.), Beliefs about Text and Instruction with Text (pp. 245-264). Lawrence Erlbaum, Hillsdale, NJ.

Ellis, R. (1994). Second language acquisition research and teacher development: The case of teachers' questions. In D. C. S. Li, D. Mahoney, \& J. C. Richards (Eds.), Exploring second language teacher development (pp. 175-193). Hong Kong: City Polytechnic of Hong Kong.

Ellis, R. (2008). Learner beliefs and language learning. ASIAN EFL Journal, 10(4), 7-24.

Eslami-Rasekh, Z., \& Valizadeh, K. (2004). Classroom activities viewed from different perspectives: Learners' voice and teachers' voice. TESL-EJ, 8,3 .

Gan, Z. (2004). Attitudes and strategies as predictors of self-directed language learning in an EFL context. International Journal of Applied Linguistics, 14(3).

Gardner, R. C. (1985). Social Psychology and Second Language Learning: The Role of Attitude and Motivation. London: Edward Arnold.

Green, J. M., \& Oxford, R. (1995). A Closer Look at Learning Strategies, L2 Proficiency and Gender. TESOL Quarterly, 29(2), 261-297.

Gu, Y. (2002). Introduction to the special issue of learning and teaching English in the Chinese context. Asian Journal of English Language Teaching, 12, 1-4.

Harmer, J. (1991). The Practice of English language Teaching. London: Longman.

Hampton, S. (1994). Teacher change: Overthrowing the myths of one teacher, one classroom. In T. Shanahan (Ed.), Teachers thinking, teachers knowing (pp. 122-140). Illinois: NCRE.

Hinkel, E. (1999). Culture in Second Language Teaching and Learning. Cambridge: Cambridge University press. 
Horwitz, E. K. (1985). Using student beliefs about language learning and teaching in the foreign language methods course. Foreign Language Annals, 18(4), 333-340.

Horwitz, E. K. (1987a). Beliefs about Language Learning Inventory (BALLI, ESL/EFL Version). Unpublished manuscript.

Horwitz, E. K. (1987b). Surveying student beliefs about language learning. In A. L.Wenden, \& J. Rubin (Eds.), Learner Strategies in Language Learning (pp. 119-129). London: Prentica-Hall.

Horwitz, E. K. (1988). The beliefs about language learning of beginning university foreign language students. The Modern Language Journal, 72(3), 283-294.

Incecay, G. (2011). Pre-service Teachers' Language Learning Beliefs and Effects of these Beliefs on their Practice Teaching. Procedia Social and Behavioral Sciences, 15, 128-133.

Intaraprasert, C. (2004). An investigation of beliefs about learning English by Thai and Vietnamese universities science-oriented students: A cross-cultural perspective (Unpublished).

Johnson, K. E. (1994). The emerging beliefs and instructional practices of pre-service English as a second language teachers. Teaching and Teacher Education, 10(4), 439-452.

Jones, J. (1999). From silence to talk: Cross-cultural ideas on students' participation in academic group discussion. English for Specific Purposes, 18(3), 243-259.

Kagan, D. M. (1992). Implications of research on teacher belief. Educational Psychologist, 27(1), 65-90.

Kern, R. G. (1995). Students' and teachers' beliefs about language learning. Foreign Language Annals, 28(1), 71-92.

Lortie, D. C. (1975). School-teacher: A sociological study. Chicago: The University of Chicago Press.

Mantle-Bromley, C. (1995). Positive attitudes and realistic beliefs: Links to proficiency. Modern Language Journal, 79(3), 372-386.

Mori, Y. (1999). Epistemological beliefs and language learning beliefs: What do language learners believe about their learning? Language Learning, 49(3), 377-415.

Nespor, J. (1987). The role of beliefs in the practice of teaching. Journal of Curriculum Studies, 19, 317-328.

Oxford, R., \& Burry-Stock, J. A. (1995). Assessing the Use of Language Learning Strategies Worldwide with the ESL/EFL Version of the Strategy Inventory for Language Learning (SILL). System, 23(1), 1-23.

Pajares, M. F. (1992). Teachers' beliefs and educational research: Cleaning up a messy construct. Review of Educational Research, 62, 307-322.

Peacock, M. (1999). Beliefs about language learning and their relationship to proficiency. International Journal of Applied Linguistics, 9(2), 247-265.

Richards, J. C., \& Lockhart, C. (1994). Reflective teaching in second language classrooms. Cambridge: Cambridge University Press.

Richards, J. C., Gallo, P. B., \& Renandya, W. A. (2001). Exploring teachers' beliefs and the processes of change. The PAC Journal, 1(1), 41-62.

Riley, P. (1996). "BATS and BALLS": Beliefs about talk and beliefs about language learning. Proceedings of the International Conference AUTONOMY 2000: The development of learning independence in language learning, Bangkok, November, 151-168.

Sakui, K., \& Gaies, S. J. (1999). Investigating Japanese learners' beliefs about language learning. System, 27, 473-492.

Suwanarak, K. (2013). Relationships among Beliefs, Learning Strategies, and Achievement in Learning English of Thai Graduate Students in a Public University. ABAC Journal, 33(1), 20-37.

Tatto, M. T. (1998). The influence of teacher education on teachers' beliefs about purposes of education, roles, and practice. Journal of Teacher Education, 49(1), 66-77.

Truitt, S. N. (1995). Anxiety and beliefs about language learning: A study of Korean university students learning English (Unpublished doctoral dissertation, University of Texas at Austin, USA).

Tsui, A. (1996). Reticence and anxiety in second language learning. In K. Bailey, \& D. Nunan (Eds.), Voices from the Language Classroom (pp. 145-167). Cambridge University Press, Cambridge. 
Vibulphol, J. (2004). Beliefs about language learning and teaching approaches of pre-service EFL teachers in Thailand (Unpublished Dissertation, Oklahoma State University).

Wang, J. (2008). Beliefs about English Language Learning Held by Chinese University Students and Teachers in the People's Republic of China (Unpublished doctoral dissertation, Suranaree University of Technology, Thailand).

Wen, Q., \& Johnson, R. K. (1997). L2 learner variables and English achievement: A study of tertiary-level English majors in China. Applied Linguistics, 18, 27-48.

Wenden, A. L. (1986a). Helping language learners think about learning. ELT Journal, 40, 3-19.

Wenden, A. L. (1986b). What do second-language learners know about their language learning? A second look at retrospective accounts. Applied Linguistics, 7, 186-201.

Wenden, A. L. (1987a). How to be a successful language learner: Insights and prescriptions from L2 learners. In A. L. Wenden, \& J. Rubin (Eds.), Learner Strategies in Language Learning (pp. 103-118). Prentice-Hall, Englewood Cliffs, NJ.

Wenden, A. L. (1999). An introduction to metacognitve knowledge and beliefs in language learning: Beyond the basics (Special Issue). System, 27, 435-441.

Williams, M., \& Burden, R. L. (1997). Psychology for language teachers: A social constructivist approach. Cambridge: Cambridge University Press.

Wright, T. (1987). Roles of Teachers and Learners. Oxford University Press.

Yang, N. D. (1999). The relationship between EFL learners' beliefs and learning strategy use. System, 27, 515-535.

Young, R. (1987). The cultural context of TESOL-A review of research into Chinese classroom. RELC Journal, $18,15-30$.

\section{Appendix}

Instructions: Read each statement carefully and put a $(\checkmark)$ for the response which best indicates the extent to which you agree or disagree with each of the following statements.

1) Strongly Disagree

2) Disagree

3) Not Sure

4) Agree

5) Strongly Agree

Example:

\begin{tabular}{llllll}
\hline Statements of Beliefs & 1 & 2 & 3 & 4 & 5 \\
\hline 0: It is important to speak English with an excellent accent. & & & & $\checkmark$ \\
\hline
\end{tabular}

\begin{tabular}{|c|c|c|c|c|c|}
\hline Statements of Beliefs & 1 & 2 & 3 & 4 & \\
\hline It is easier for children than adults to learn English. & & & & & \\
\hline Some people are born with a special ability which helps them learn English. & & & & & \\
\hline English is a difficult language. & & & & & \\
\hline 4. A teacher should correct every time when students make mistakes. & & & & & \\
\hline 5. I believe that I will ultimately learn to speak English very well. & & & & & \\
\hline 6. Laotians are good at learning English. & & & & & \\
\hline It is necessary to speak English with an excellent accent. & & & & & \\
\hline 8. It is necessary to know English culture in order to speak English well. & & & & & \\
\hline 9. I should not say anything in English until I can say it correctly. & & & & & \\
\hline $\begin{array}{l}\text { 10. People who are good at mathematics or science are not good at learning } \\
\text { English. }\end{array}$ & & & & & \\
\hline 11. It is better to learn English in an English-speaking country. & & & & & \\
\hline 12. I can improve my English if I often chat with English native speakers. & & & & & \\
\hline
\end{tabular}


13. It is OK to guess if I do not know the meaning of a new word in English.

14. I have English language aptitude.

15. Learning English is mostly a matter of learning a lot of new vocabulary words.

16. It is important to repeat and practice a lot in class.

17. Women are better than men at learning English.

18. If you are allowed to make mistakes in the beginning, it will be hard to get rid of such mistakes later on.

19. I feel shy or uncomfortable when I speak English in front of other people.

20. Learning English is a matter of learning a lot of grammar rules.

21. I would like to learn English so that I can make friends with foreigners.

22. It is easier to speak than to understand English.

23. Multi-media is very useful in learning English.

24. Learning English is different from learning other school subjects.

25. It is very important to learn English through translation from English into Lao and Lao into English.

26. If I learn to speak English very well, it will help me get a good job.

27. Only a native speaker can teach me to speak English very well.

28. Without a teacher, learning English is impossible for me.

29. Extra-curricular activities enable me to learn English well.

30. Nowadays Lao people think it is very important to learn English.

31. I would like to have friends from foreign country.

32. Laotians can learn and communicate in English.

33. It is easier to read and write English than to speak and understand it.

34. It depends on the teacher to make students like or dislike learning English.

35. I learn English only to pass the exam.

36. A teacher should speak Lao as much as he/she can while teaching.

37. The teacher is the best resource person for me to learn English.

38. Doing a self-study in English outside class is very helpful.

39. It is important to practice English in the language laboratory.

\section{Copyrights}

Copyright for this article is retained by the author(s), with first publication rights granted to the journal.

This is an open-access article distributed under the terms and conditions of the Creative Commons Attribution license (http://creativecommons.org/licenses/by/3.0/). 